\title{
Immunohistochemical changes in sigmoid colon after allogeneic and autologous bone marrow transplantation
}

\author{
G M Forbes, W N Erber, R P Herrmann, J M Davies, B J Collins
}

\begin{abstract}
Aim-To determine whether there are characteristic immunohistological changes in the colonic mucosa in acute graft versus host disease (GvHD).

Methods-Consecutive allogeneic $(n=11)$ and autologous $(n=11)$ bone marrow transplant recipients underwent endoscopic biopsy of sigmoid mucosa before transplant and on day 30 post-transplant. Immunohistochemical staining and quantitation of intraepithelial and lamina propria mononuclear cells were undertaken using a panel of monoclonal antibodies and a Streptavidin-biotin alkaline phosphatase staining technique.

Results-In the allogeneic group (nine of whom had clinical acute GvHD) there was a fivefold increase in lamina propria CD16 + mononuclear cells $(3 \cdot 1 \pm 4 \cdot 3$ to $17 \cdot 0 \pm 12 \cdot 2$ per 100 lamina propria nucleated cells), compared with autologous transplant recipients in whom this rise was twofold $(5 \cdot 5 \pm 4 \cdot 6$ to $10 \cdot 6 \pm 7 \cdot 1$ per 100 lamina propria nucleated cells). The CD16 + mononuclear cells had morphological appearances of tissue macrophages, but in neither the allogeneic nor autologous groups was there an increase in total macrophage numbers (CD14+). In patients with acute GvHD the lamina propria CD4+:CD8 + lymphocyte ratio fell $(1.97 \pm 1 \cdot 12$ to $1.07 \pm 1 \cdot 01)$, primarily because of a fall in the number of lamina propria CD4 + lymphocytes. In both allogeneic and autologous groups there was a fall in intraepithelial lymphocyte numbers, but there was no change in CD19+ (B cell), CD25 + (interleukin-2 receptor positive) or $\mathrm{CD} 56+$ (natural killer) cell numbers.

Conclusion-Following bone marrow transplantation, there appears to be upregulation of lamina propria tissue macrophage CD16 (an Fc receptor for IgG), a change which is more noticeable after allogeneic transplantation and which may be related to the development of acute GvHD. In patients with acute GvHD there was a fall in the lamina propria CD4+: CD8 + lymphocyte ratio. If these changes are functionally important, they may have significant implications for understanding the pathogenesis of GvHD. (f Clin Pathol 1995;48:308-313)
\end{abstract}

Keywords: Acute GvHD, bone marrow, transplantation.
Gastrointestinal disturbance following bone marrow transplantation is often multifactorial and may be caused by the effects of the chemoradiation preparative regime, infections or graft versus host disease (GvHD). ${ }^{12}$ Between 50 and $75 \%$ of HLA matched allogeneic bone marrow transplant (BMT) recipients develop GvHD, ${ }^{3}$ a syndrome which predominantly affects the skin, gastrointestinal tract and liver, and is a major cause of morbidity and mortality in these patients. GvHD is arbitrarily divided into acute and chronic using a temporal cut off of 100 days post-transplant; ${ }^{4}$ chronic GvHD may evolve from acute GvHD or develop de novo. ${ }^{124}$ By convention, the diagnosis of GvHD is clinically based, in conjunction with histology of skin or rectal biopsy.

The pathophysiology of GvHD is incompletely understood, hence limiting advances in preventive and therapeutic strategies. Post-thymic donor $\mathrm{T}$ cells are considered to play a major role in the development of this syndrome as $\mathrm{T}$ cell depletion of donor marrow reduces the frequency and severity of GvHD. ${ }^{5}$ It is unknown whether donor $T$ cells are of primary pathogenic significance, or simply a mediator in a more complex process; ${ }^{6}$ indeed, work in animal models has suggested that cytokines, including those released by tissue macrophages, play an important role in mediating tissue injury in GvHD. ${ }^{7}$

The few immunopathological studies of human intestinal GvHD that have been undertaken vary, both in the method of quantitation of mucosal mononuclear cells, and whether biopsy specimens were taken at a time of acute or chronic GvHD. ${ }^{8-10}$ It appears that it is not possible to directly compare other target organs of GvHD, such as skin and liver, with the gastrointestinal tract as mononuclear cell populations have been found to differ in these sites. ${ }^{8}$ To date, there have been few studies comparing post-transplant immunohistological appearances with those pretransplant. Sviland et al described upregulation of enterocyte HLA-DR following allogeneic BMT, a change which also occurs on keratinocytes and biliary epithelium. ${ }^{112}$ Weisdorf and coworkers found that in four patients with acute GvHD there was a fall in the lamina propria $\mathrm{CD} 4+: \mathrm{CD} 8+$ lymphocyte ratio and a rise in intraepithelial and lamina propria CD57 + cells (which include natural killer cells), when compared with pretransplant levels. ${ }^{10}$

We undertook a detailed immunohistological study of colonic mucosa in both allogeneic and 
autologous BMT recipients, both before and after transplantation, to determine whether there were characteristic changes which were specific to patients with GvHD.

\section{Methods}

Of 29 patients undergoing allogeneic or autologous BMT at Royal Perth Hospital between April 1992 and July 1993, 25 agreed to participate in this study. Flexible sigmoidoscopy and sigmoid colon mucosal biopsy were performed within two weeks before transplant and on day 30 post-transplant. Prophylactic antibiotics were administered in accordance with Gastroenterological Society of Australia guidelines, ${ }^{13}$ and we ensured the platelet count was greater than $50 \times 10^{12} / 1$ at the time of each examination to minimise the risk of bleeding following endoscopic biopsy. Two biopsy specimens from each examination were forwarded for standard histological examination. A clinical and histological grade of GvHD was assigned to allogeneic BMT recipients and their post-transplant biopsy specimen according to a five stage grading system (0-IV), as outlined elsewhere. ${ }^{1415}$ In the analysis of data patients with GvHD were defined as those with "clinical" GvHD, as the presence and severity of this condition are imprecisely defined histologically. Clinical GvHD was defined as the presence of appropriate symptoms or clinical signs in combination with supportive histology (of skin, gastrointestinal mucosa or liver).

\section{IMMUNOCYTOCHEMICAL STUDIES}

An additional mucosal biopsy was placed in OCT embedding media, snap frozen in liquid nitrogen and stored at $-70^{\circ} \mathrm{C}$. Subsequently, $4 \mu \mathrm{m}$ cryostat sections placed on poly-L-lysine coated slides were air-dried overnight before fixing in acetone. Using a panel of monoclonal antibodies (table 1) mucosal mononuclear cells were characterised by a Streptavidin-biotin alkaline phosphatase staining technique with minor modifications of the manufacturer's recommendations (Dako quick staining kit, alkaline phosphatase K 687. Dako, Carpinteria, USA). Briefly, sections were incubated with mouse primary antibody for 15 minutes in a moist chamber at room temperature. As negative controls, TRIS buffered saline (TBS) was used in place of primary antibody. A second seven minute incubation with a biotinylated

Table 1 Monoclonal antibodies used, their cellular distribution and the positively stained cells counted

\begin{tabular}{llll}
\hline Antibody & CD number & Cellular distribution & Cells counted \\
\hline Dako-T11 & 2 & Pan-T cell, NK cell & All positive cells \\
Dako-T3 & 3 & Pan-T cell & All positive cells \\
Dako-T4 & 4 & T helper cell, macrophages & Lymphocytes \\
X107* & 8 & T suppressor cell & All positive cells \\
MY4 (Coulter) & 14 & Macrophages & All positive cells \\
DJ130* & 16 & Pan-B cell & All positive cells \\
Dako-CD19 & 19 & Interleukin-2 receptor (activated T & All positive cells \\
and B cells and activated & \\
& 25 & macrophages) & All positive cells \\
4KB5* & 45RA & Leucocyte common antigen isoform & Lymphocytes \\
Dako-UCHL-1 & 45RO & NK cell, neuroectodermal cell & Lymphocytes \\
VJ13A & 56 & All positive cells \\
\hline
\end{tabular}

* Antibodies provided by Dr D Mason, Oxford. rabbit antimouse antibody was followed by a seven minute incubation with alkaline phosphatase labelled Streptavidin. Naphthol ASMX phosphate and fast red chromogenic substrate was applied for 20 minutes before counterstaining with haematoxylin. Two one minute washes in TBS were performed between each incubation.

\section{IMMUNOHISTOLOGICAL ANALYSIS}

Methods of quantitation of mucosal mononuclear cells vary and this lack of uniformity has not only made comparison between studies difficult but certain methods are arguably flawed and influence interpretation of results. In keeping with aspects of the methodology of Weisdorf et $a l^{10}$ and de Silva et al ${ }^{16}$ we believe the method of quantitation as described below is appropriate for colonic mucosal immunopathological studies.

Sections were examined by light microscopy at $\times 400$ magnification. Positively staining mononuclear cells were identified by their intense circumferential red staining, and were quantitated according to intraepithelial or lamina propria location in areas distant to lymphoid follicles. Intraepithelial lymphocytes were counted in areas of intact epithelium, in vertically orientated crypts from surface to base; numbers were expressed per 100 epithelial cells, after counting a minimum of 500 epithelial cells. Lamina propria mononuclear cells were counted in areas of intact lamina propria, and in areas incorporating the full depth of the lamina propria to the muscularis mucosa. This was particularly important for analysis of positively staining macrophages which are predominant in the superficial lamina propria. Lamina propria mononuclear cell numbers were expressed as a percentage of the total number of lamina propria nucleated cells, by counting a minimum of 500 lamina propria nucleated cells. In view of the lack of cell lineage specificity exhibited by a number of monoclonal antibodies ${ }^{17}$ concomitant histological analysis was required to differentiate certain cell types. The specific cell type stained by a given monoclonal antibody and thereafter counted is outlined in table 1 .

\section{STATISTICAL ANALYSIS}

Differences between pre- and post-transplant mononuclear cell numbers were analysed using the Wilcoxon signed rank test. A p value of less than 0.05 was considered significant.

ETHICS

The study received approval from the Royal Perth Hospital Ethics Committee and from the Human Rights Committee of the University of Western Australia. Written informed consent was obtained from each patient before entry into the study.

\section{Results}

CLINICAL DETAILS

Of 25 patients who agreed to participate in this 
Table 2 Clinical details of patients

\begin{tabular}{|c|c|c|c|c|}
\hline & Allogeneic $(n=11)$ & & Autologous $(n=11)$ & \\
\hline \multirow{3}{*}{$\begin{array}{l}\text { Age (mean; } \\
\text { years) } \\
\text { Sex } \\
\text { Disease }\end{array}$} & $21-51(37)$ & & $22-64(37)$ & \\
\hline & five $M$, six $F$ & & nine $M$, two $F$ & \\
\hline & $\begin{array}{l}\text { Acute myeloid leukaemia } \\
\text { Chronic myeloid leukaemia } \\
\text { Acute lymphoblastic leukaemia } \\
\text { Multiple myeloma } \\
\text { Non-Hodgkin's lymphoma }\end{array}$ & $\begin{array}{l}4 \\
4 \\
1 \\
1\end{array}$ & $\begin{array}{l}\text { Non-Hodgkin's lymphoma } \\
\text { Hodgkin's disease } \\
\text { Acute myeloid leukaemia }\end{array}$ & $\begin{array}{l}5 \\
3 \\
3\end{array}$ \\
\hline \multirow[t]{2}{*}{$\begin{array}{l}\text { Preparative } \\
\text { regime }\end{array}$} & $\begin{array}{l}\text { Total body irradiation/ } \\
\text { cyclophosphamide }\end{array}$ & 5 & $\begin{array}{l}\text { BCNU/etoposide/ara-C/ } \\
\text { melphalan }\end{array}$ & 8 \\
\hline & Busulphan/cyclophosphamide & 6 & $\begin{array}{l}\text { Busulphan/cyclophosphamide } \\
\text { BCNU/etoposide/ } \\
\text { cyclophosphamide }\end{array}$ & $\begin{array}{l}2 \\
1\end{array}$ \\
\hline
\end{tabular}

study, three critically unwell allogeneic BMT recipients did not undergo the day 30 examination and all three subsequently died by day 50 post-transplant. This left 11 allogeneic and 11 autologous patients for study, the clinical details of whom are set out in table 2 .

Of the 11 allogeneic BMT recipients, three were HLA matched unrelated donor transplants and the remainder were HLA matched related donor transplants. GvHD prophylaxis was with methotrexate and cyclosporin $(n=$ $11)$, intravenous immunoglobulin $(n=4)$, and all matched unrelated donor transplant recipients received marrow depleted of $T$ cells through ex vivo use of the pan $T$ cell monoclonal antibody Campath 1G (CD52). Marrow engraftment in allogeneic patients was achieved by day 17 (mean, range 10-23 days) post-transplant, as defined by a peripheral neutrophil count of greater than $0.5 \times 10^{9} / 1$. Clinical acute GvHD occurred in nine allogeneic patients (grade I in six, grade II in two and grade III in one), with involvement of skin in eight, liver in two and gastrointestinal tract in two. Of these nine patients, histological evidence of acute GvHD in the sigmoid mucosa was present in seven; grade I in five and grade II in two. Four patients had received corticosteroid therapy for up to seven days before the day 30 examination following a clinical diagnosis of GvHD. Sigmoidoscopic appearances were normal in all examinations with the exception of one patient with acute GvHD in whom there was mild distal patchy proctocolitis with punctate superficial ulceration.

\section{IMMUNOPATHOLOGICAL RESULTS}

For both allogeneic and autologous patient groups, there was no change in numbers of lamina propria $\mathrm{T}$ cells $(\mathrm{CD} 2+$ or $\mathrm{CD} 3+)$ from pretransplant to day 30 post-transplant. In allogeneic patients there was a reduction in the number of intraepithelial lymphocytes $(\mathrm{CD} 2+, \mathrm{CD} 3+$ and $\mathrm{CD} 8+)$ which reached statistical significance for $\mathrm{CD} 2+$ cells and $\mathrm{CD} 8+$ lymphocytes in those with acute GvHD. There was a significant fall in intraepithelial CD2 +, CD3 + and CD8 + cells in autologous patients. Very few lamina propria lymphocytes or macrophages expressed the interleukin-2 receptor (CD25) pretransplant, and there was no increase in $\mathrm{CD} 25+$ cell numbers post-transplant. There was no change in lamina propria CD56+ (natural killer or

Table 3 Intraepithelial mononuclear cell numbers, pre- and post-transplant, in allogeneic and autologous transplant groups

\begin{tabular}{|c|c|c|c|c|c|c|}
\hline & \multicolumn{3}{|c|}{$\begin{array}{l}\text { Allogeneic patients: } n=11 \\
\text { (clinical GvHD only: } n=9 \text { ) }\end{array}$} & \multicolumn{3}{|c|}{ Autologous patients: $n=11$} \\
\hline & Pre-BMT & Day +30 & $p$ & Pre-BMT & Day +30 & $p$ \\
\hline $\mathrm{CD} 2$ & \multirow{4}{*}{$\begin{array}{c}3.6 \pm 2.0 \\
(3.6 \pm 1.9) \\
3.8 \pm 1 \cdot 8 \\
(3.9 \pm 2.0) \\
0.2 \pm 0.3 \\
(0.2 \pm 0.3) \\
4.0 \pm 2.0 \\
(4.6 \pm 1.7)\end{array}$} & \multirow{4}{*}{$\begin{array}{c}1.9 \pm 1.5 \\
(1.7 \pm 1.4) \\
2.5 \pm 1.4 \\
(2.6 \pm 1.4) \\
0.2 \pm 0.2 \\
(0.2 \pm 0.2) \\
2.6 \pm 1.5 \\
(2.5 \pm 1.5)\end{array}$} & \multirow[t]{3}{*}{$\begin{array}{l}0.026 \\
(0.051)\end{array}$} & $3 \cdot 3 \pm 2 \cdot 0$ & $1 \cdot 7 \pm 1 \cdot 0$ & 0.008 \\
\hline CD3 & & & & $3 \cdot 6 \pm 1 \cdot 5$ & $1 \cdot 7 \pm 0 \cdot 8$ & 0.010 \\
\hline $\mathrm{CD} 4$ & & & & $0 \cdot 2 \pm 0 \cdot 3$ & $0 \cdot 1 \pm 0 \cdot 2$ & \\
\hline CD8 & & & $(0.044)$ & $3 \cdot 6 \pm 1 \cdot 7$ & $1.8 \pm 0.9$ & 0.022 \\
\hline
\end{tabular}

Intraepithelial lymphocyte numbers expressed per 100 epithelial cells. Figures given as mean $\pm S D$, and p values given when $\mathrm{p}<0 \cdot 1$.

Table 4 Lamina propria mononuclear cell numbers, pre-and post-transplant, in allogeneic and autologous transplant groups

\begin{tabular}{|c|c|c|c|c|c|c|}
\hline & \multicolumn{3}{|c|}{$\begin{array}{l}\text { Allogeneic patients: } n=11 \\
\text { (clinical GvHD only: } n=9 \text { ) }\end{array}$} & \multicolumn{3}{|c|}{ Autologous patients: $n=11$} \\
\hline & Pre-BMT & Day +30 & $p$ & Pre-BMT & Day +30 & $p$ \\
\hline $\mathrm{CD} 2$ & $\begin{array}{c}17 \cdot 1 \pm 4 \cdot 4 \\
(17 \cdot 4 \pm 4 \cdot 8)\end{array}$ & $\begin{array}{c}14 \cdot 0 \pm 7 \cdot 7 \\
(14 \cdot 8+8 \cdot 4)\end{array}$ & \multirow{4}{*}{$\begin{array}{l}0.030 \\
(0.06)\end{array}$} & $14 \cdot 9 \pm 4 \cdot 7$ & $12 \cdot 6 \pm 3 \cdot 1$ & \\
\hline CD3 & $\begin{array}{l}16 \cdot 2 \pm 2 \cdot 6 \\
(16 \cdot 3 \pm 2 \cdot 9)\end{array}$ & $\begin{array}{l}15 \cdot 1 \pm 8 \cdot 3 \\
(16 \cdot 1 \pm 9 \cdot 0)\end{array}$ & & $15 \cdot 2 \pm 8 \cdot 5$ & $14 \cdot 8 \pm 5 \cdot 1$ & \\
\hline CD4 & $\begin{array}{l}11.4 \pm 3.7 \\
(11.6 \pm 4 \cdot 1)\end{array}$ & $\begin{array}{r}7 \cdot 6 \pm 3 \cdot 8 \\
(7 \cdot 5 \pm 4 \cdot 2)\end{array}$ & & $7 \cdot 6 \pm 2 \cdot 9$ & $7 \cdot 9 \pm 2 \cdot 5$ & \\
\hline CD8 & $\begin{array}{c}7 \cdot 3 \pm 3 \cdot 0 \\
(6 \cdot 6 \pm 2 \cdot 7)\end{array}$ & $\begin{array}{c}7 \cdot 7 \pm 5 \cdot 2 \\
(8 \cdot 6 \pm 5 \cdot 4)\end{array}$ & & $6 \cdot 9 \pm 3 \cdot 0$ & $5 \cdot 5 \pm 3 \cdot 8$ & \\
\hline CD4/CD8 & $\begin{array}{c}1.81 \pm 1.07 \\
(1.97 \pm 1.12)\end{array}$ & $\begin{array}{l}1.27 \pm 1.01 \\
(1.07 \pm 1.01)\end{array}$ & \multirow[t]{2}{*}{$(0.038)$} & $1.28 \pm 0.71$ & $2 \cdot 06 \pm 1 \cdot 37$ & 0.09 \\
\hline CD14 & $\begin{array}{l}18 \cdot 5 \pm 4 \cdot 4 \\
(18 \cdot 2 \pm 4 \cdot 3)\end{array}$ & $\begin{array}{l}19 \cdot 3 \pm 5.0 \\
(20 \cdot 2 \pm 5 \cdot 1)\end{array}$ & & $20 \cdot 0 \pm 6 \cdot 0$ & $22 \cdot 0 \pm 5 \cdot 8$ & \multirow{4}{*}{0.026} \\
\hline CD16 & $\begin{array}{c}3.1 \pm 4 \cdot 3 \\
(3 \cdot 5 \pm 4 \cdot 6)\end{array}$ & $\begin{array}{l}17 \cdot 0 \pm 12 \cdot 2 \\
(18 \cdot 9 \pm 12 \cdot 8)\end{array}$ & \multirow{3}{*}{$\begin{array}{c}0.004 \\
(0.011) \\
0.07 \\
(0.09)\end{array}$} & $5 \cdot 5 \pm 4 \cdot 6$ & $10 \cdot 6 \pm 7 \cdot 1$ & \\
\hline CD25 & $\begin{array}{l}3 \cdot 0 \pm 2 \cdot 3 \\
(3 \cdot 0 \pm 2 \cdot 4)\end{array}$ & $\begin{array}{l}1.4 \pm 1.0 \\
(1.5 \pm 1.0)\end{array}$ & & $1 \cdot 4 \pm 1.9$ & $1 \cdot 0 \pm 1 \cdot 0$ & \\
\hline CD56 & $\begin{array}{l}8 \cdot 3 \pm 3 \cdot 5 \\
(8 \cdot 3 \pm 3 \cdot 7)\end{array}$ & $\begin{array}{l}7 \cdot 9 \pm 3 \cdot 1 \\
(8 \cdot 3 \pm 3 \cdot 2)\end{array}$ & & $9 \cdot 4 \pm 3 \cdot 1$ & $9 \cdot 5 \pm 2 \cdot 7$ & \\
\hline
\end{tabular}

Lamina propria mononuclear cell numbers expressed per 100 lamina propria nucleated cells. Figures given as mean $\pm S D$, and $\mathrm{p}$ values given when $\mathrm{p}<0 \cdot 1$. 
NK) cell numbers in either allogeneic or autologous BMT recipients (tables 3 and 4). Only occasional CD19 + cells (B lymphocytes) were present in the lamina propria with the exception of within lymphoid follicles. No CD19+, CD25 + or CD56 + mononuclear cells were present within an intraepithelial location in any sections. The normal predominance of CD45RO + (primed or memory) $\mathrm{T}$ cells in the intraepithelial and lamina propria compartments was present in all day 30 sigmoid biopsy specimens, and CD45RA + (unprimed or naive) $\mathrm{T}$ cells were uncommon in all sections except within lymphoid follicles.

There was a fivefold rise in lamina propria $\mathrm{CD} 16+$ mononuclear cell (cells bearing the Fc $\gamma$ RIII, an Fc receptor for IgG) numbers in the allogeneic BMT group $(3 \cdot 1 \pm 4 \cdot 3$ to $17 \cdot 0 \pm 12 \cdot 2$ cells per 100 lamina propria nucleated cells; $\mathrm{p}=0.004$ ) and in those with a clinical diagnosis of acute $\operatorname{GvHD}(p=0.011)$. The rise in lamina propria CD16 + mononuclear cell numbers was most marked in patients with clinical GvHD of grade II or III, none of whom received intravenous immunoglobulin prophylaxis against GvHD. By light microscopy, the CD16 + cells had morphological appearances of tissue macrophages located predominantly in the superficial lamina propria (figure). There was, however, no change in total macrophage numbers (CD14+ mononuclear cells), suggesting upregulation of lamina propria tissue macrophage CD16 in these patients. In the autologous BMT group there was also a significant rise in lamina propria $\mathrm{CD} 16+$ mononuclear cell numbers although this was of smaller magnitude than in the allogeneic group $(5 \cdot 5 \pm 4 \cdot 6$ to $10 \cdot 6 \pm 7 \cdot 1$ cells per 100 lamina propria nucleated cells; $\mathrm{p}=0.026$ ); again, there was no change in total macrophage numbers.

There was a significant fall in the lamina propria CD4 + :CD8 + lymphocyte ratio in allogeneic BMT recipients with GvHD $(1.97 \pm 1.12$ to $1.07 \pm 1.01 ; \mathrm{p}=0.038)$, largely caused by a fall in lamina propria CD4+ lymphocyte numbers $(p=0.06)$. By contrast, in the autologous BMT group, there was a trend for the lamina propria $\mathrm{CD} 4+: \mathrm{CD} 8+$ lymphocyte ratio to rise $(p=0.09)$ but there was no consistent change in CD4 + or CD8 + $T$ cell numbers.

\section{Discussion}

There are very limited data on immunopathological findings in the gastrointestinal mucosa in GvHD. This is the first study to compare mononuclear cell populations in the gastrointestinal mucosa before and after allogeneic and autologous BMT. In doing so, we have confirmed some of the findings of other studies of human intestinal GvHD and extended observations further. Previous studies of human intestinal GvHD have concentrated largely on changes in mucosal lymphoid cell populations; by contrast, our study has demonstrated an alteration in mucosal mononuclear cells of monocytic lineage following BMT.

The increase in CD16+ mononuclear cell numbers in allogeneic BMT recipients raised the possibility that upregulation of the Fc $\gamma$ RIII on tissue macrophages is part of a sequence of pathogenic events in intestinal GvHD. An alternative to upregulation of CD16 is an influx

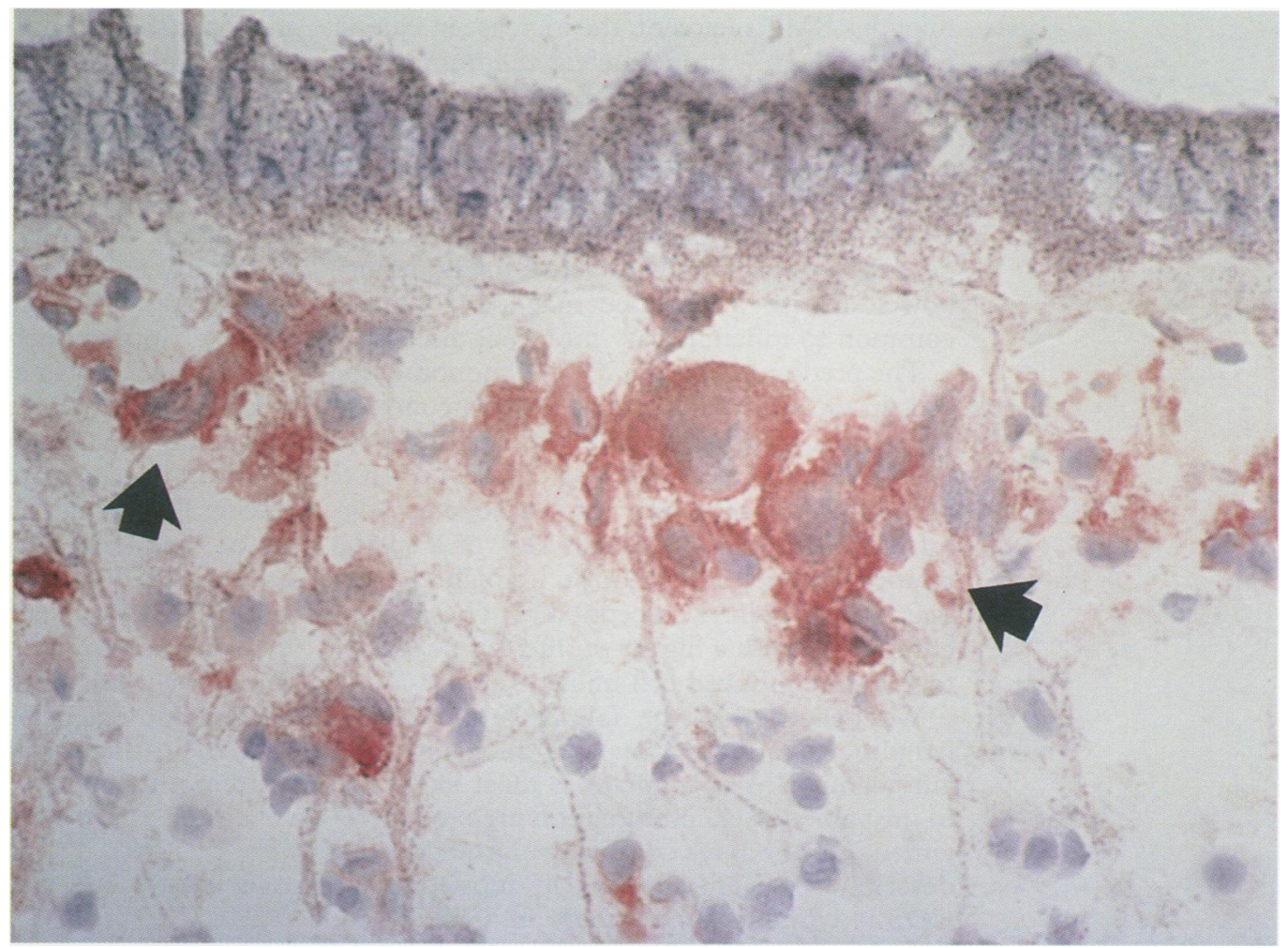


of CD16 + mononuclear cells, although the absence of a rise in lamina propria macrophage numbers does not support this. CD16 may be expressed on macrophages, NK cells and neutrophils ${ }^{18}$; in our study most CD16+ mononuclear cells had the morphological appearances of macrophages, and although some may have been NK cells, there was no increase in mononuclear cell numbers of NK cell phenotype $(\mathrm{CD} 56+)$. Binding of immune complex with the Fc $\gamma$ RIII of macrophages may mediate a number of events, including cytokine release or release of other mediators of inflammation, antibody dependent cell cytotoxicity, phagocytosis, and clearance of immune complexes. ${ }^{1920}$ Our finding that CD16 appears to be upregulated on lamina propria tissue macrophages after allogeneic BMT is consistent with the hypothesis that cytokines play a role in mediating tissue injury in GvHD. It is interesting to speculate that one way in which intravenous immunoglobulin might be protective against GvHD is by blocking macrophage cell surface Fc $\gamma$ RIII. This possibility is supported by our observation that the three patients in whom there was greatest CD16 upregulation did not receive immunoglobulin prophylaxis and had grade II or III GvHD.

The autologous patient group also had a significant rise in lamina propria CD16+ mononuclear cell numbers but of smaller magnitude than the allogeneic transplant recipients. It is possible that the increase in lamina propria $\mathrm{CD} 16+$ mononuclear cell numbers in both patient groups was a result of the chemoradiation preparative regime. However, GvHD has been reported to occur following autologous BMT, for reasons that remain unclear. $^{21}$ Although there was no clinical or histological evidence of GvHD in any autologous BMT recipient, the increase in lamina propria CD16 + mononuclear cell numbers in the autologous transplant group may represent an early immunological event in the pathogenesis of GvHD which does not progress to overt disease. An increase in lamina propria $\mathrm{CD} 16+$ mononuclear cell numbers has been described in patients with active inflammatory bowel disease and hence may be a finding common to inflammatory intestinal diseases. ${ }^{22}$

The predominance of CD16 + mononuclear cells in the superficial lamina propria contrasts with the crypt base being the main site of mucosal injury in GvHD. If these CD16+ mononuclear cells are of pathogenic significance, the reason for this lack of a spatial relation is unclear, although it might be explained by a greater susceptibility of basal crypt enterocytes with a higher proliferative capacity to cytokine induced cell injury.

We believe that the fall in intraepithelial lymphocyte numbers in both allogeneic and autologous BMT recipients is most likely due to the sublethal chemoradiation preparative regimen. Our findings contrast with the previous description of an increase in intraepithelial $\mathrm{CD} 8+$ lymphocyte numbers in $\mathrm{GvHD}^{8}{ }^{8}$ although in that study there were methodological differences in intraepithelial lymphocyte quantitation and acute and chronic GvHD were not differentiated. The same group described no change in lamina propria macrophage numbers and no evidence of mucosal lymphocyte activation (using CD25, OKT10 and HLA-DR), ${ }^{8}$ findings in keeping with ours. Interleukin-2 (IL-2) is believed to be an important cytokine in the pathogenesis of GvHD, ${ }^{23}$ as it is critical for the activation and proliferation of $\mathrm{T}$ lymphocytes. The role of IL-2 as an effector cytokine in GvHD tissue injury has been difficult to establish ${ }^{2324}$ and its importance in the context of a paucity of IL-2 receptor + $(\mathrm{CD} 25+)$ mononuclear cells is unclear. Notably, all allogeneic BMT recipients received cyclosporin which inhibits IL-2 synthesis and IL-2 receptor expression ${ }^{25}$ and this may explain the lack of an increase in CD25+ mononuclear cell numbers. Indeed, it is unclear to what extent GvHD prophylaxis and corticosteroid therapy may have altered the immunohistological findings in our patients, but it is difficult, if not impossible, to control for these factors in human studies of GvHD. No immunohistological differences, however, were noted after BMT between allogeneic transplant recipients who received corticosteroids and those who did not.

The alteration in ratio of lamina propria CD4 + and CD8 + T lymphocytes in GvHD in our study is in keeping with other reports, ${ }^{810}$ although one group found that there was a significant increase in lamina propria CD8 + $T$ cell numbers in patients who had either acute or chronic GvHD. ${ }^{8}$ A relative excess of T cells of cytotoxic suppressor phenotype over $T$ helper cells supports the role of donor cytotoxic $\mathrm{T}$ cells playing a role in mediating GvHD, particularly as the fall in the lamina propria $\mathrm{CD} 4+: \mathrm{CD} 8$ + lymphocyte ratio was not seen in autologous transplants. Previous data on mucosal NK cell numbers are conflicting. Our findings parallel those of Dilly and Sloane who found no change in lamina propria CD56+ mononuclear cell numbers and no intraepithelial CD56 + cells, ${ }^{8}$ although the absence of a rise in mucosal NK cell numbers does not necessarily preclude NK cell mediated tissue injury. By contrast, Weisdorf $e t a l^{10}$ described in four patients with acute GvHD, a fourfold rise in intraepithelial and lamina propria CD57 + cells, also a marker of NK cells.

Our findings suggest that the tissue macrophage in the lamina propria of the sigmoid colon is in a heightened state of activity following BMT, and it is possible that this might be of functional significance in patients who are at risk of developing GvHD. If mononuclear cell CD16 upregulation is of importance, then cytokine release and subsequent mucosal cell injury may be the direct consequence. The therapeutic extension of such a hypothesis is that these might provide attractive targets of immunotherapy.

Financial assistance was received from the Royal Perth Hospital Medical Research Foundation. GMF was a WA and MG Saw Postgraduate Medical Research Fellow of the University Western Australia. Part of this work was presented in abstract form at the Australian Gastroenterology Week 1993 (f Gastroenterol Hepatol 1993;8:A32) and at the Royal College of Pathologists of Australasia annual 
1 McDonald GB, Shulman HM, Sullivan KM, Spencer GD. Intestinal and hepatic complications of human bone marrow transplantation. Part 1. Gastreenterology 1986;90:460 77.

2 McDonald GB, Shulman HM, Sullivan KM, Spencer GD Intestinal and hepatic complications of human bone marrow transplantation. Part 2. Gastroenterology 1986;90:770 84.

3 Marks DI, Cullis JO, Ward KN, Lacey S, Szydlo R, Hughes $\mathrm{TD}$, et al. Allogeneic bone marrow transplantation fo chronic myeloid leukemia using sibling and voluntee unrelated donors. Ann Intern Med 1993;119:207-14.

4 Atkinson K. Chronic graft-versus-host disease. Bone Marrow Transplant 1990;5:69-82.

5 Ferrara JLM, Deeg HJ. Graft-versus-host disease. $N$ Engl $\mathcal{F}$ Med 1991;324:667-74.

6 Appleton AL, Sviland L. Current thoughts on the pathogenesis of graft-versus-host disease. F Clin Pathol 1993; 46:785-9.

7 Mowat AMcI. Intestinal graft-versus-host disease. In $\mathrm{McD}$ onald TT, ed. Immunology of gastrointestinal disease. Dordrecht: Klewer, 1992:105-36.

8 Dilly SA, Sloane JP. Changes in rectal leucocytes after allogeneic bone marrow transplantation. Clin Exp Immunol 1987;67:151-8.

9 Nakhleh RE, Snover DC, Weisdorf S, Platt JL. Immunopathology of graft-versus-host disease in the upper grastrointestinal tract. Transplantation 1989;48:61-5.

10 Weisdorf SA, Roy J, Snover D, Platt JL, Weisdorf DJ. Inflammatory cells in graft-versus-host disease of the Inflammatory cells in graft-versus-host disease of the rectum: immunopatho

11 Sviland L, Pearson ADJ, Eastham EJ, Green MA, Hamilton PJ, Proctor SJ, et al. Class II antigen expression by keratinocytes and enterocytes - an early feature of graftversus-host disease. Transplantation 1988;46:402-6.

12 Dilly SA, Sloane JP. An immunohistological study of human graft-versus-host disease. Clin Exp Immunol 1985;62:54553 .

13 Cowan AE, Denham J, Rayner T. Infection and endoscopy. Gastroenterological Society of Australia, 1992.
14 Weisdorf DJ, Snover DC, Haake R, Miller WJ, McGlave PB, Blazer B, et al. Acute upper gastrointestinal graftversus-host disease: clinical significance and response to immunosuppressive therapy. Blood 1990;76:624-9.

15 Sloane JP, Norton J. The pathology of bone marrow transplantation. Histopathology 1993;22:201-9.

16 de Silva JH, Jones M, Prince C, Kettlewell M, Mortensen NJ, Jewell DP. Lymphocyte and macrophage sub populations in pelvic ileal pouches. Gut 1991;32:1160-5.

17 Forbes GM, Erber WN, Collins BJ. Lack of cell lineag specificity of monoclonal antibodies extends to the gastrointestinal mucosa [abstract]. $f$ Gastroenterol Hepatol 1993;8:A43.

18 Schmidt RE, Perussia B. Cluster report: CD16. In: Knapp B, Dorken B, Gilks WR, Rieber EP, Schmidt RE, Stein $\mathrm{H}$, et al, eds. White cell differentiation antigens. Oxford: Oxford University Press, 1989:574-8.

19 Unkeless JC, Scigliano E, Freedman VH. Structure and function of human and murine receptors for IgG. Ann function of human and murin

20 Fridman WH. Fc receptors and immunoglobulin binding factors. FASEB f 1991;5:2684-90.

21 Hood AF, Vogelsang GB, Farmer ER, Santos GW. Acute graft-versus-host disease: development following autologous and syngeneic bone marrow transplantation. Arch Dermatol 1987;123:745-50.

22 Mahida YR, Patel S, Gionchetti P, Vaux D, Jewell DP. Macrophage subpopulations in lamina propria of normal and inflamed colon and terminal ileum. Gut 1989;30. and infiam 34.

23 Antin JH, Ferrara JLM Cytokine dysregulation and acute graft-versus-host disease. Blood 1992;80:2964-8.

24 Rowbottom AW, Norton J, Riches PG, Hobbs JR, Powles RL, Sloane JP. Cytokine gene expression in skin and lymphoid organs in graft-versus-host disease. $\mathcal{F}$ Clin Pathol 1993;46:341-5.

$25 \mathrm{Li} \mathrm{B}$, Sehejpal PK Subramaniam A, Joseph A, Stenzel $\mathrm{KH}$, Suthanthiran $\mathrm{M}$. Inhibition of interleukin-2 recepto expression in normal human $T$ cells by cyclosporine. Demonstration at mRNA, protein and functional levels. Transplantation 1992;53:146-51. 